\title{
Persona Design Method for Evaluating Business Skills
}

\author{
Takao Terano \\ Department of Computational Intelligence and Systems Science, \\ Tokyo Institute of Technology \\ Address: 2 Chome-12-1 Ookayama, Meguro, Tokyo 152-8550, Japan \\ E-mail: terano@dis.titech.ac.jp
}

Yasuhiro Sasaki

Department of Computational Intelligence and Systems Science, Tokyo Institute of Technology

E-mail: sasaki.yasuhiro@gmail.com

Masaaki Kunigami Department of Computational Intelligence and Systems Science, Tokyo Institute of Technology E-mail: mkunigami@nifty.ne.jp Atsushi Yoshikawa
Department of Computational Intelligence and Systems
Science, Tokyo Institute of Technology
E-mail: at_sushi_bar@dis.titech.ac.jp

Abstract: This paper describes a novel method to apply the persona design method in marketing science to the human resource management domain. Using the technique, employees in a business firm can identify and rank the images of the business skills the ideal leaders of an IToriented organization. To clarify the differences in recognition, we apply the persona technique. The persona technique was started in the user interface field of computer software development or marketing strategies, and has spread to the product development field. The proposed method uses the following procedure: 1) set persona characters with various attributes, 2) assign the attribute values by the orthogonal design technique, 3) design questionnaires, 4) get questionnaire data on the personas from subjects, 5) evaluate the data recorded on respondent questionnaires. Using the proposed method, we successfully detected the ordering of different employee images of organization leaders.

Keywords: Personas; Competency; Leadership; Personal requirements; Human Resource developments. 


\section{INTRODUCTION}

According to Bennis[1], leaders are made, not born, and moreover are primarily selfmade. We also support this view that leaders can be cultivated. Leaders play very important roles in business organizations, and their capabilities influence the rise and fall of their organizations. Leaders guide and inspire subordinates. Excellent leaders can give their organizations a competitive advantage. Therefore, it is essential for business organizations to cultivate excellent leaders.[2]

However, research on leader training in human resource management is incomplete. The capabilities leaders require are not uniform, and leaders must also be well versed in the operations of their organizations. Moreover, leaders must maintain smooth relations between bosses and subordinates. Furthermore, they need to learn the conceptual capabilities necessary to understand and map enterprises. Since business conditions differ among organizations, it is impossible to uniformly define the capabilities leaders require. This is one reason that research on leader image is difficult.

In marketing and user-centered design, personas are virtual characters created to represent different user types within a targeted demographic, attitude or behavior set that might use a site, brand or product in similar ways. [4] Personas are useful in considering the goals, desires, and limitations of brand buyers and users to help guide supplier decisions about a service, product or interaction space, such as the features, interactions, and visual design of a website. Personas may also be used in a user-centered design process for software design, and are also considered a part of interaction design, having been used in industrial design and more recently for online marketing. A user persona represents the goals and behavior of a hypothesized group of users. Generally, personas are synthesized from data collected through interviews with users, and are presented in one-page descriptions that include behavior patterns, goals, skills, attitudes, and environment, with a few fictional personal details to make the persona a realistic character.

Alan Cooper, a noted pioneer software developer, developed the concept of personas. From 1995 he became interested in how specific, rather than generalized, users would use and interface with software. The persona concept was popularized for the online business and technology community in Cooper's 1999 book "The Inmates are running the Asylum".[3] In this book, Cooper outlined the general characteristics, uses and best practices for creating personas, and recommended that developers design software for single archetypal users.

In this paper, we applied the persona technique to draw images of corporate leaders. Usually, minute fixed-quantity investigation and close qualitative investigation are required for "persona" creation. [5] In fact, this level of expense, time and effort is unnecessary for "persona" creation. We demonstrate this in this research, which devises a simple technique that collateralizes fixed rationality and probability.

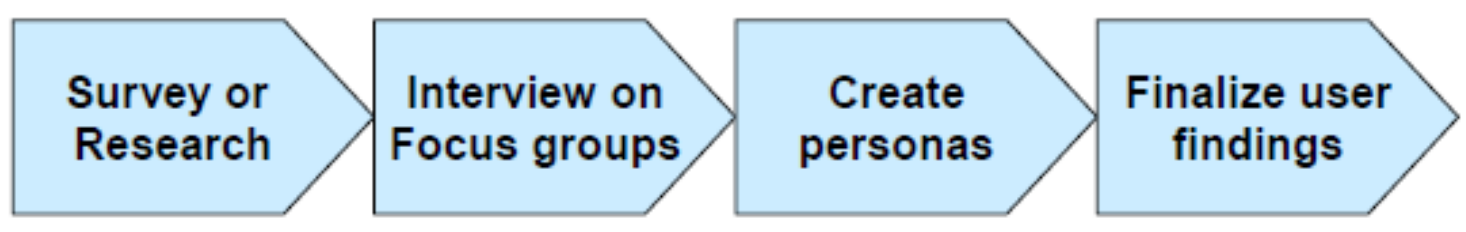

Fig. 1. Usual persona generation and measure examination process 


\section{PURPOSE OF THE RESEARCH}

Identification of desirable leader characteristics is a central concern in the knowledge management literature. However, different business environments require different types of business leaders. Business environments that change too fast make it difficult to achieve agreement about desirable leader characteristics. This paper proposes a novel method to identify desirable leader images using virtual characters. We use personas to research leader characteristics.[8]

By application of an experimental design, we aim to minimize the number of questionnaire items that subjects must select from. We aim to obtain high-precision results with a small sample by utilizing conjoint analysis.[7]

The proposed method is summarized as follows: 1 ) set persona characters with various attributes, 2) assign the attribute values by orthogonal design techniques, 3) set virtual business situations, 4)obtain questionnaire data on the personas from subjects based on the business situations, and 5) evaluate the data to get the leader images for the corresponding business situations.

\section{BRIEF DESCRIPTION OF THE PROPOSED METHOD}

\section{Assigning Leaders Based on Capability Requirements}

Previous research [6] on the leader image of ICT organizations probed 25 competencies as capabilities required for leaders. The paper identified nine core competencies by systematic examination as the most important capability requirements, as summarized in Table 1.

Table 1. MAIN CAPABIIITY REQUIREMENTS EXPECTED OF BUSINESS LEADERS

\begin{tabular}{|l|l|l|}
\hline No. & \multicolumn{1}{|c|}{ Competency } & \multicolumn{1}{c|}{ The example of action } \\
\hline 1 & Practical Skill & $\begin{array}{l}\text { The thing required for mind and logic composition for which it has } \\
\text { deep knowledge broadly and moderately }\end{array}$ \\
\hline 2 & Positiveness & $\begin{array}{l}\text { The subject of a high level is set up actively and the best is always } \\
\text { concentrated towards achievement. }\end{array}$ \\
\hline 3 & Judgment & $\begin{array}{l}\text { It can judge [whether while there is an uncertain element, a project } \\
\text { can be promoted and it can lead to a success, and] by itself. }\end{array}$ \\
\hline 4 & $\begin{array}{l}\text { Cultivating } \\
\text { Human Resource }\end{array}$ & $\begin{array}{l}\text { Advice according to the feature and characteristic of a place of work } \\
\text { and the member of a project is performed. }\end{array}$ \\
\hline 5 & Visio & $\begin{array}{l}\text { Business planning, such as a development project which can } \\
\text { promote two or more proposal affair efficiently, is drawn up. }\end{array}$ \\
\hline 6 & Communication & $\begin{array}{l}\text { A confidential relation with a partner can be built through "hearing } \\
\text { it" and "talking." }\end{array}$ \\
\hline 7 & Negotiation & $\begin{array}{l}\text { The merit to the company by developing a system is recognized, and } \\
\text { in-company adjustment can be carried out. }\end{array}$ \\
\hline
\end{tabular}

Of course, a person who excels in all capabilities is ideal. However, there are few such business leaders and expecting young leaders to have such capabilities is unrealistic. We thus created the orthogonal array listed in TABLE 2 to prompt experimental subjects to choose talented people who were suitable business leaders. Using the orthogonal array listed in Table 2, we could perform many comparisons despite few selections. 
Table 2. COMBINATION OF CAPABILITIES OF BUSINESS LEADERS

\begin{tabular}{|c|l|l|l|l|l|l|c|}
\hline & $\begin{array}{l}\text { Practical } \\
\text { Skill }\end{array}$ & $\begin{array}{l}\text { Posit } \\
\text {-iveness }\end{array}$ & Judgment & $\begin{array}{l}\text { Cultivating } \\
\text { HR }\end{array}$ & Vision & $\begin{array}{l}\text { Commu } \\
\text {-nication }\end{array}$ & Negotiation \\
\hline typeA & - & - & - & - & - & - & - \\
\hline typeB & - & - & - & 0 & 0 & 0 & 0 \\
\hline typeC & - & 0 & 0 & - & - & 0 & 0 \\
\hline typeD & - & 0 & 0 & 0 & 0 & - & - \\
\hline typeE & 0 & - & 0 & - & 0 & - & 0 \\
\hline typeF & 0 & - & 0 & 0 & - & 0 & - \\
\hline typeG & $\mathrm{O}$ & $\mathrm{O}$ & - & - & 0 & 0 & - \\
\hline typeH & $\mathrm{O}$ & $\mathrm{O}$ & - & 0 & - & - & 0 \\
\hline
\end{tabular}

(L8 array)

In this array, Type A denotes a leader with average performance in all capabilities, while Types $\mathrm{B}$ to $\mathrm{H}$ denote leaders who excel in different sets of four capabilities.

\section{Experiment Setup}

The experiment was designed as follows. We prepared the questionnaire vote. Respondents individually answered questions about the following three cases. To ensure conformity of responses to the case, we asked respondents to attach leader type rankings to their responses.

Table 3. SETUP OF EACH CASE

\begin{tabular}{|l|l|}
\hline Case 1 & $\begin{array}{c}\text { The situation of organizations } \\
\text { The achievements of this organization tend to descend. If the leader } \\
\text { does not take bold measures, this organization does not have the future. }\end{array}$ \\
\hline Case 2 & $\begin{array}{l}\text { The achievements of this organization are upward. The atmosphere of } \\
\text { this organization is bright. }\end{array}$ \\
\hline Case 3 & $\begin{array}{l}\text { The achievements of this organization are safe for the time being. } \\
\text { However, the future of this organization is slightly opaque. }\end{array}$ \\
\hline
\end{tabular}

We printed eight personas (from Type A to Type $\mathrm{H}$ ) on small pieces of paper, and arranged them on the desk. We put such papers in order at random for every respondents. We then asked respondents to rearrange those papers in descending order of the degree to which they described the ideal leadership of the organization in the subject case. Respondents rearranged the papers into order suitable as a leader of the case. Respondents repeated this examination 3 times. Respondents entered ranking in the answer sheet for every case. (Fig. 2) 

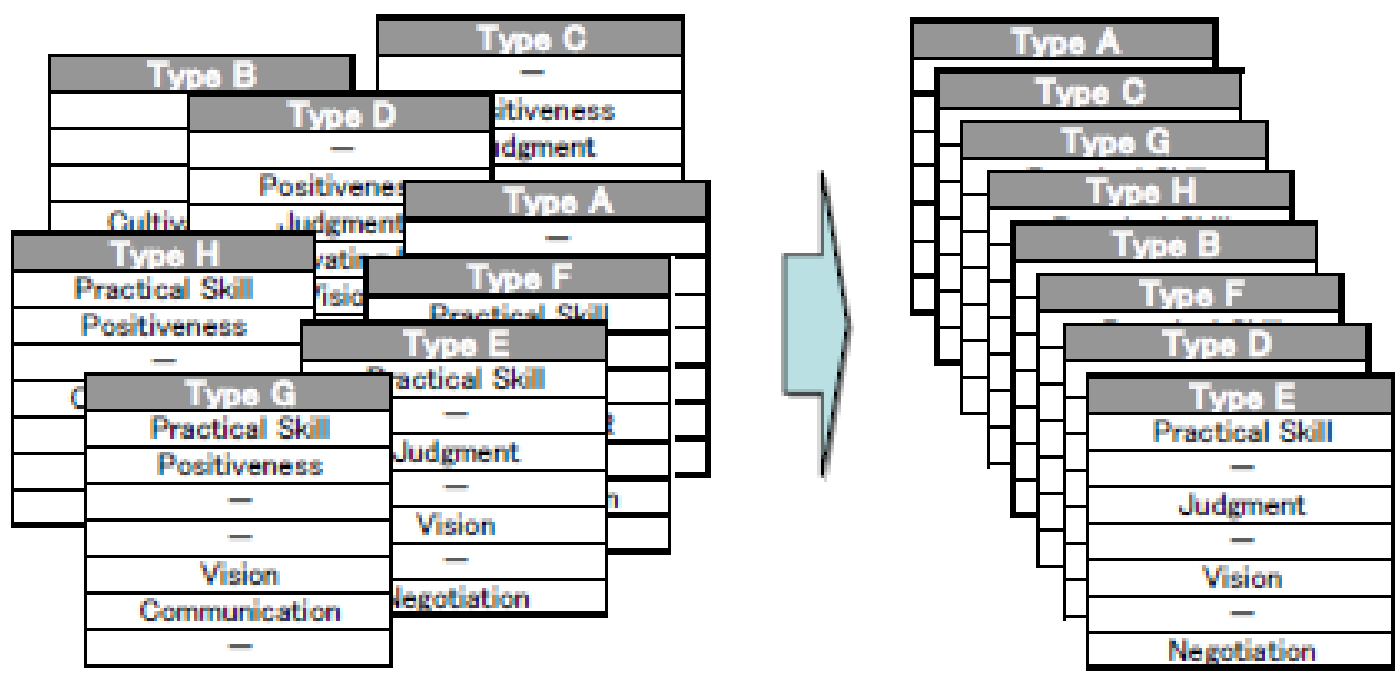

Fig. 2. Rearrangement of cards by respondents (image)

We administered the questionnaire, and collected reply data from 25 respondents, at the following three locations:

1. A Tokyo Institute of Technology graduate school seminar: 13 respondents

2. The Mitsubishi study group: 5 respondents

3. A specific society seminar hall: 7 respondents

Table 4. THE COLLECTION RESULT OF ANSWER SHEETS

\begin{tabular}{|l|c|c|c|c|c|c|c|}
\hline Place & All & Male & Female & $\begin{array}{c}\text { Bore than 20years } \\
\text { in service }\end{array}$ & 11-20years in service & $\begin{array}{c}\text { no more than 10years } \\
\text { in service }\end{array}$ & $\begin{array}{c}\text { Postgraduate Student } \\
\text { (not in service) }\end{array}$ \\
\hline \hline 1$)$ & 13 & 11 & 2 & 6 & 2 & 2 & 3 \\
\hline 2$)$ & 5 & 5 & & 1 & 4 & & \\
\hline 3$)$ & 7 & 6 & 1 & 1 & 2 & 4 & 3 \\
\hline Total & 25 & 22 & 3 & 8 & 8 & 6 & \\
\hline
\end{tabular}

\section{RESULTS AND DISCUSSION}

\section{Results of Respondent Assessments of Leader Capability Requirements}

Below we analyze the questionnaire results using the orthogonal array. The seven competencies were allocated to each persona by the L-8 orthogonal array. We analyzed which of the leader competencies respondents considered important when they ranked (the best: 1st the worst: 8th) the leader personas. Subsequently, besides conjoint-analysis, we applied multiple regression analysis to determine the sensitivity of the respondents' evaluations. In the multiple regression analysis, the response variable is "score (= 8 - rank, the best: 7 - the worst: 0$)$ " and 
the explanatory variables are the existence of the seven competencies ( $0-1$ data, absence: 0 , existence: 1). The multiple regression analysis under the three cases of organizational situation (sample size 25each) illustrates how the seven competencies contribute to the score. Each of the regression coefficients of the 7 competencies illustrates how the existence of each competency contributes to the score of rank. We call these coefficients "score contribution". The set of the score contribution is expected to change reflecting the difference of the organizational situations or the difference of the subjects' expectation to their leaders.

\section{Case 1 (an organization with declining achievements)}

The most important capability requirements needed for the business leader in this organization are "imagination and vision", followed by "judgment" and "positive attitude and drive to succeed". Clearly different from both cases 2 and 3 , the outcome shows that the relatively short range competencies become clearly significant instead of the relatively long range one (Cultivating HR). The effect-size: $r 2$ (coefficient of determination) $=0.35 .^{1}$

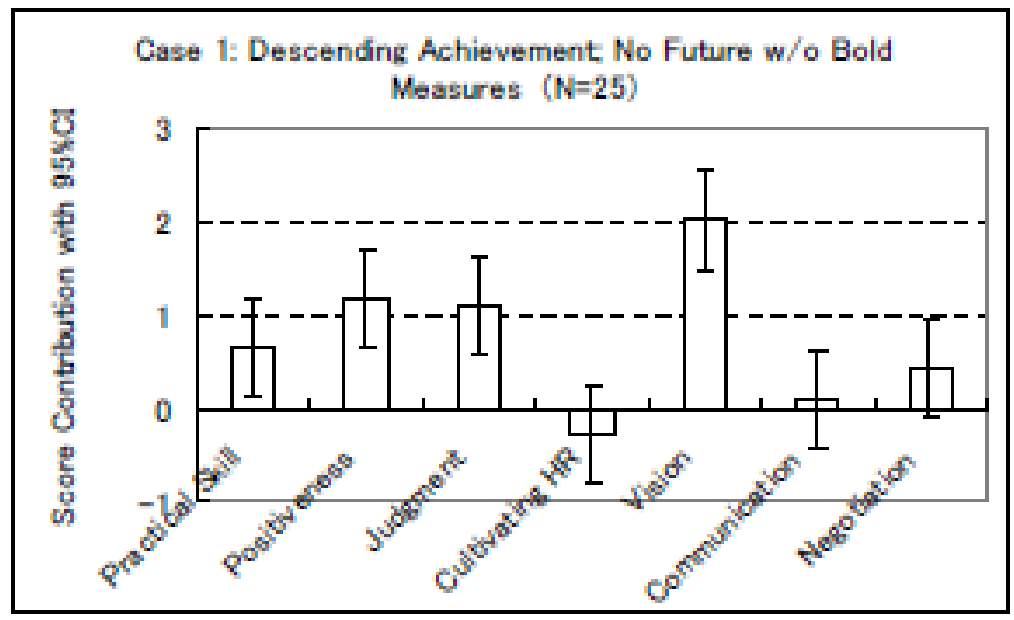

Fig. 3. (Case 1) Capability requirements in low performance organization

\section{Case $\mathbf{2}$ (an organization with increasing achievements)}

The most important capability requirement for the business leader in this organization is "subordinate training" capability. There was no significant difference between the seven competencies, and the effect-size: $r 2$ (coefficient of determination) $=0.08$.

1 Cohen[10] shows that Cohen's delta of 0.08 (equivalent to $r$-squared of 0.138 ) suggests big difference (as large as the difference of average IQ between $\mathrm{PhD}$ students and undergraduate students). Therefore, our outcomes (r-squared of 0.35 and 0.29 ) show considerably strong effect on the subjects' preference of the leaders' competency. 


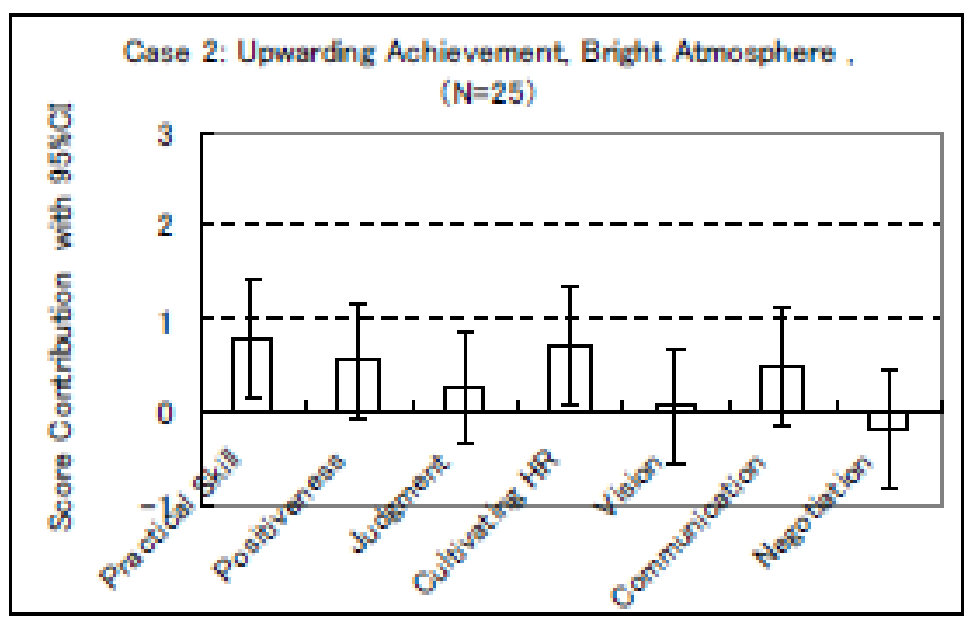

Fig. 4. (Case 2) Capability requirements in a high performance organization

The null hypothesis "capability elements do not influence selection of leaders" was not disposed in this Case 2.

\section{Case $\mathbf{3}$ (an organization with stable achievements)}

The most important capability requirements for business leaders in this organization are "imagination and vision", and "subordinate training." Clearly different from Case 2, the outcome shows that the middle - long range (Vision, Cultivating HR) competencies are clearly significant. The effect-size: $r 2$ (coefficient of determination) $=0.29 .1$.

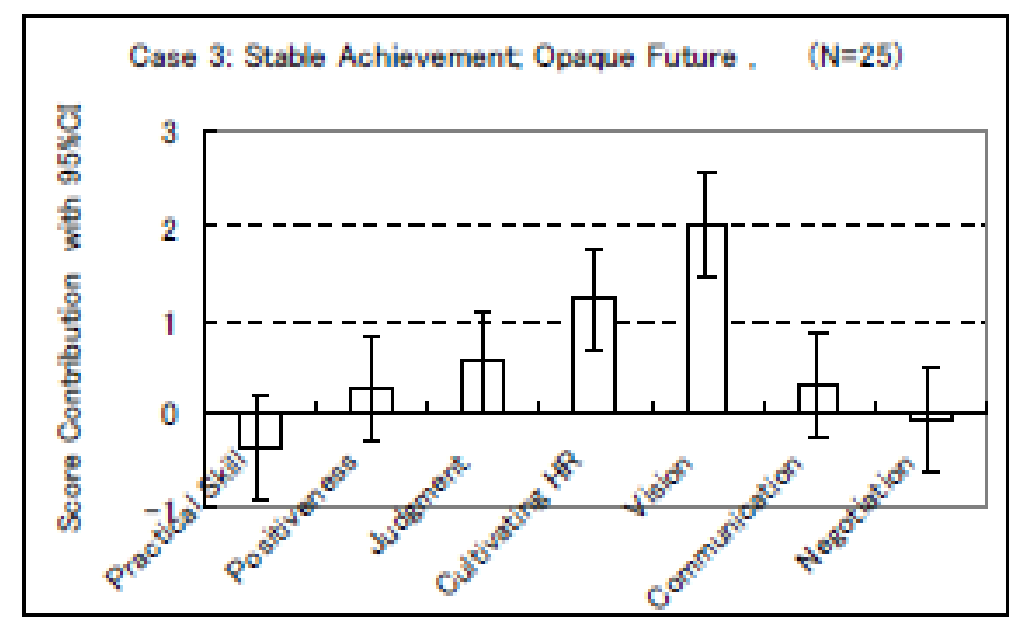

Fig. 5. (Case 3) Capability requirements in a poor performance organization

The null hypothesis "capability elements do not influence selection of leaders" was disposed in this Case 3. 


\section{Influence of Respondent Years of Service on Recognition of Leader Capability Requirements}

The previous subsection confirmed that leaders' capability requirements change with organizational situation. The confirmation involved checking respondent recognition of leaders' capability requirements using the persona technique and orthogonal array. This method of confirmation raises the question of whether respondent recognition of leader capability requirements differed based on respondent attributes such as years of service.

In this section, we describe the results of checking for differences in responses arising from respondents' attributes. We divided respondents according to years of service, and conducted multiple linear regression analysis. A thin shading cell indicates a coefficient of one or more, while a deep shading cell indicates a coefficient of two or more. Certain items influence respondent ranking of leader capability requirements.

\section{Case 1 (an organization with declining achievements)}

Every group of respondents identify "Vision" as a significant capability requirement for leaders. However, other capability requirements vary among different groups of respondents. For example, employees with a medium level of experience (defined as 11-20 years of service), and students recognize "Practical Skills" as important, while employees with a high level of experience do not.

\section{Table 5. (CASE 1) CAPABILITY REQUIREMINTS}

\begin{tabular}{|c|c|c|c|c|c|c|c|c|}
\hline Category & & $\begin{array}{l}\text { Practical } \\
\text { Stsill }\end{array}$ & $\begin{array}{c}\text { Posit } \\
\text {-iveness }\end{array}$ & Judgument & $\begin{array}{c}\text { Culfivating } \\
\text { HR. }\end{array}$ & Vision & $\begin{array}{l}\text { Coumma } \\
\text {-nication }\end{array}$ & Negotiation \\
\hline All & $\mathrm{N}=25$ & 0.7 & 1.2 & 1.1 & -0.3 & 2.0 & 0.1 & 0.4 \\
\hline $\begin{array}{l}\text { Businesspeople } \\
\text { more than } 20 \text { vears in service }\end{array}$ & $\mathrm{N}=8$ & 0.3 & 0.5 & 1.2 & -0.5 & 1.8 & 0.1 & 0.6 \\
\hline $\begin{array}{l}\text { Businesspeople } \\
11 \text {-20 wears in service }\end{array}$ & $\mathrm{N}=8$ & 1.2 & 1.3 & 0.9 & -0.6 & 2.2 & -0.1 & 0.7 \\
\hline $\begin{array}{l}\text { Businesspeople } \\
\text { mo more than } 1 \text { Onears in garvice }\end{array}$ & $\mathrm{N}=5$ & 0.0 & 1.3 & 1.1 & 0.2 & 2.6 & 0.9 & 0.1 \\
\hline $\begin{array}{l}\text { Postgraduate Scudent } \\
\text { (not in service) }\end{array}$ & $N=4$ & 1.1 & 2.1 & 1.3 & 0.3 & 1.4 & -0.6 & 0.0 \\
\hline
\end{tabular}

\section{Case $\mathbf{2}$ (an organization with growing achievements)}

In case 2, there is no significant difference in the overall capability requirements. Recognition of the capability requirements varies among every category of respondents. In the senior category (businesspeople with more than 20 years of service), "Practical Skills" are recognized as important. In the junior category (Businesspeople with less than 10 years of service), "Judgment" is recognized as important. 
Table 6. (CASE 2) CAPABIITY REQUIREMINTS

\begin{tabular}{|c|c|c|c|c|c|c|c|c|}
\hline Category & & $\begin{array}{c}\text { Practical } \\
\text { Skill } \\
\end{array}$ & $\begin{array}{c}\text { Posit } \\
\text {-iveness } \\
\end{array}$ & Judguent & $\begin{array}{c}\text { Culfivating } \\
\text { HR. }\end{array}$ & Vision & $\begin{array}{l}\text { Conmena } \\
\text {-nication }\end{array}$ & Negotiation \\
\hline All & $\mathrm{N}=25$ & 0.8 & 0.6 & 0.3 & 0.7 & 0.1 & 0.5 & -0.2 \\
\hline $\begin{array}{l}\text { Businesspeople } \\
\text { more than } 20 \text { vears in service }\end{array}$ & $\mathrm{N}=8$ & 1.1 & 0.0 & -0.1 & 0.8 & -0.1 & 0.9 & 0.6 \\
\hline $\begin{array}{l}\text { Businesspeople } \\
11-20 \text { vears in service }\end{array}$ & $\mathrm{N}=8$ & -0.1 & 1.3 & 0.0 & 0.9 & 0.1 & 0.6 & 0.1 \\
\hline $\begin{array}{l}\text { Businesspeople } \\
\text { no more than } 10 \text { vears in service }\end{array}$ & $\mathrm{N}=5$ & 0.9 & 0.6 & 1.3 & -0.5 & 0.0 & -0.3 & -1.8 \\
\hline $\begin{array}{l}\text { Postgraduate Srudent } \\
\text { (not in service) }\end{array}$ & $N=4$ & 1.6 & 0.1 & 0.3 & 1.6 & 0.3 & 0.3 & -0.1 \\
\hline
\end{tabular}

\section{Case $\mathbf{3}$ (an organization with stable achievements)}

In case 3, "Vision" is most important to leaders' capability requirements, followed by "Cultivating HR". Recognition of the capability requirements for leaders varies among every category of respondents. Respondents who were senior employees did not consider "Cultivating $H R$ " important. Meanwhile, junior employees and students considered "Judgment" to rank next in importance.

Table 7. (CASE 3) CAPABIITY REQUIREMINTS

\begin{tabular}{|l|l|c|c|c|c|c|c|c|}
\hline Category & & $\begin{array}{c}\text { Practical } \\
\text { Slill }\end{array}$ & $\begin{array}{c}\text { Posit } \\
\text {-iveness }\end{array}$ & Judguvent & $\begin{array}{c}\text { Cultivating } \\
\text { HR }\end{array}$ & Vision & $\begin{array}{c}\text { Commmi } \\
\text {-mication }\end{array}$ & Negotiation \\
\hline \multicolumn{1}{|c|}{ All } & $\mathrm{N}=25$ & -0.4 & 0.3 & 0.6 & 1.2 & 2.0 & 0.3 & -0.1 \\
\hline $\begin{array}{l}\text { Businesspeople } \\
\text { more than 20vears in service }\end{array}$ & $\mathrm{N}=8$ & -0.4 & 0.4 & 0.5 & 0.9 & 1.9 & 0.3 & -0.3 \\
\hline $\begin{array}{l}\text { Businesspeople } \\
\text { 11-20wears in service }\end{array}$ & $\mathrm{N}=8$ & -0.7 & 0.3 & -0.3 & 1.4 & 2.7 & 0.4 & -0.2 \\
\hline $\begin{array}{l}\text { Businesspeople } \\
\text { no more than 10vers in service }\end{array}$ & $\mathrm{N}=5$ & 0.1 & 0.9 & 1.4 & 1.3 & 1.2 & 0.4 & 0.5 \\
\hline $\begin{array}{l}\text { Postgrachate Srudent } \\
\text { (not in service) }\end{array}$ & $\mathrm{N}=4$ & -0.1 & -0.8 & 1.4 & 1.4 & 2.0 & 0.1 & 0.0 \\
\hline
\end{tabular}

\section{CONCLUDING REMARKS}

The previous literature on competency research explored leaders' capability requirements by decomposing leaders' behavioral traits. This approach could not easily distinguish the strengths of different capability elements. In contrast, the present study identified the requirements for business leaders using a simple questionnaire. Unlike conventional research methods, the proposed technique is based on questionnaire design using an orthogonal array. We observed statistical difference using a simple situational setup. The results suggested that the images of the desired leaders, as expressed in the attributes of the designed characters, clearly differ from with the various business situations.

In the experiments in the paper, some competencies (communication or negotiation) have not shown significant contributions under all situations. These factors can be pooled into 
the error factor under the analysis of variance, and can be regarded as controlled data to the others. However, to clarify what are the controlled data, we will use a bigger orthogonal array with dummy factors in some columns as controlled data in the next experiment. The capabilities respondents identify as required in leaders differ with respondents' years of service. This demonstrates differences in recognition based on gaps in respondents' experiences.

Viitala[9] has been looking at how the subordinates and the leaders look at the need to develop their competence. The culture may also have significant effects on which kind of leaders are seen as good ones. This time, we investigated the influence of respondents' years of service. The influence of culture is also a future subject.

In future work, we plan to conduct interview sessions with excellent corporate leaders. Future work can examine the following questions:

- How are appropriate items incorporated in an orthogonal array?

- What is the most suitable method of analyzing the collected data?

- Is the simple persona used in the technique presented here appropriate compared with an originator persona?

\section{REFERENCES}

[1] Warren Bennis: “On Becoming a Leader”, Basic Books, 1989.

[2] Noel M. Tichy: "The Leadership Engine: How Winning Companies Build Leaders at Every Level ", Harper Business, 1997.

[3] Alan Cooper: "The inmates are running the asylum: Why high tech products drive us crazy and how to restore the sanity", Macmillan, 1999.

[4] Grudin, J. \& Pruitt, J.: "Personas, participatory design, and product development: An infrastructure for engagement". Proc. PDC 2002, 144-161.

[5] John Pruitt, Tamara Adlin "The Persona Lifecycle: Keeping People in Mind Throughout Product Design (Interactive Technologies)", Morgan Kaufmann, 2006.

[6] Yasuhiro Sasaki, Atsushi Yoshikawa and Takao Terano, "Identifying and Evaluating Next ICT Leaders of a Company - A Competency Oriented Approach -", Advances in education research, 2012 2nd International Conference on Education and Education Management(EEM2012), Information Engineering Research Institute, pp282-pp288, 2012.

[7] Masaaki Kunigami \& Takao Terano, Experiments Based Management and Administrative Science - A Manifesto -, Proc. of General conference on Emerging Arts of Research on management and administration (GEAR2012), 2012. 
[8] Hikaru Uchida, Akiko Orita, Masaaki Kunigami, Atsushi Yoshikawa, Takao Terano. "Persona Conjoint Method: Measuring Learners' Latent Understandings and the Effect of Stereotypes in Complex Business Situations", Grace Hopper Celebration of Women in Computing (GHC2012), The Anita Borg Institute For Women And Technology, 2012.

[9] Riitta Viitala, "Towards knowledge leadership", Leadership \& Organization Development Journal, Vol. 25 Iss: 6, pp.528-544, 2004.

[10]Jacob Cohen, "Statistical power analysis for the behavioral science (2nd ed.)", Routledge Academic, 1988. 